Is Critique Secular? 
This page intentionally left blank 


\title{
Is Critique Secular? Blasphemy, Injury, and Free Speech
}

\author{
Talal Asad \\ Wendy Brown \\ Judith Butler \\ Saba Mahmood
}

With a New Preface by the Authors 


\section{Copyright @ 2013 Fordham University Press}

Originally published as The Townsend Papers in the Humanities, no. 2, by The Townsend Center for the Humanities, University of California, Berkeley.

All rights reserved. No part of this publication may be reproduced, stored in a retrieval system, or transmitted in any form or by any means-electronic, mechanical, photocopy, recording, or any other-except for brief quotations in printed reviews, without the prior permission of the publisher.

Fordham University Press has no responsibility for the persistence or accuracy of URLs for external or third-party Internet websites referred to in this publication and does not guarantee that any content on such websites is, or will remain, accurate or appropriate.

Fordham University Press also publishes its books in a variety of electronic formats. Some content that appears in print may not be available in electronic books.

Library of Congress Cataloging-in-Publication Data is available from the publisher.

Printed in the United States of America
$15 \quad 1413$
54321 